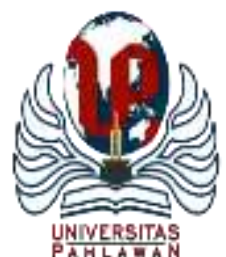

\title{
JURNALBASICEDU
}

Volume 5 Nomor 6 Tahun 2021 Halaman 5014-5023

Research \&Learningin Elementary Education

https://jbasic.org/index.php/basicedu

\section{Analisis Kesulitan Guru Sekolah Dasar Negeri Pesisir Pantai Kota Baubau dalam Pembelajaran Matematika Pada Masa Pandemik Covid-19}

\author{
Siti Rahmalia Natsir ${ }^{1 凶}$, Samritin ${ }^{2}$, Ekha Rosmitha Sari ${ }^{3}$, Amelia Ayu Lestari ${ }^{4}$, Justia $^{5}$, \\ Rahmawati $^{6}$ \\ Pendidikan Guru Sekolah Dasar, Universitas Muhammadiyah Buton, Indonesia ${ }^{1,2,3,4,5,6}$ \\ E-mail: rahmalianatsir20@gmail.com ${ }^{1}, \underline{\text { samritin75@gmail.com }}{ }^{2}, \underline{\text { ekharosmitthasari@gmail.com }}^{3}$, \\ $\underline{\text { ameliaayulestari2805@gmail.com }}^{4}$, justia183@gmail.com ${ }^{5}$, $\underline{\text { rahmawatyarizal @ gnail.com }}^{6}$
}

\begin{abstract}
Abstrak
Penelitian ini bertujuan untuk mendeskripsikan jenis kesulitan yang dialami guru matematika di pesisir pantai kota Baubau dan mendeskripsikan faktor yang menyebabkan kesulitan yang dialami oleh guru matematika di pesisir pantai Kota Baubau. Teknik analisis yang digunakan dalam penelitian ini adalah teknik analisis deskriptif kualitatif dengan mengelompokan menjadi beberapa kategori kesulitan guru dalam pembelajaran. Hasil penelitian ini menunjukan dalam kategori kesulitan yang paling banyak dialami guru dalam merencanakan proses pembelajaran yaitu menetukan media pembelajaran matematika. Hal ini disebabkan karena kurangnya kemampuan guru dalam mengembangkan media Powerpoint dalam pembelajaran dan kurangnya pengalaman guru dalam pembelajaran online. Kesulitan guru dalam melaksanakan proses pembelajaran, guru banyak mengalami kesulitan dalam menjelaskan materi matematika kesiswa dan mengetahui kemampuan siswa. Hal ini disebabkan karena guru tidak berinteraksi secara langsung dengan siswa dan terbatasnya fasilitas yang dimiliki guru maupun siswa dalam pembelajaran online. Kesulitan guru dalam berkomunikasi dengan siswa. Guru banyak mengalami kesulitan dalam menumbuhkan minat siswa dalam belajar matematika. Hal ini disebabkan karena guru minimnya keterlibatan guru dalam proses pembelajaran dan kurangnya pendampingan anak selama proses pembelajaran matematika.
\end{abstract}

Kata Kunci: Kesulitan Guru, Matematika, Covid-19

\begin{abstract}
The purpose of this study is to describe the types of difficulties experienced by mathematics teachers on the coast of Baubau City and describe the factors that cause difficulties experienced by mathematics teachers on the coast of Baubau City. The analytical technique used in this study was qualitative descriptive analysis technique by grouping into several categories of teacher difficulties in learning. The results of this study indicate that in the category of difficulties most experienced by teachers in planning the learning process, namely determining mathematics learning media. This is due to the teacher's lack of ability in developing Powerpoint media in learning and the teacher's lack of experience in online learning. The difficulty of the teacher in carrying out the learning process, the teacher has many difficulties in explaining the mathematics material to students and knowing the students' abilities. This is because teachers do not interact directly with students and the limited facilities owned by teachers and students in online learning. Difficulties of teachers in communicating with students. Many teachers have difficulty in growing students' interest in learning mathematics. This is due to the lack of teacher involvement in the learning process and the lack of assistance to children during the mathematics learning process.
\end{abstract}

Keywords: Teacher Difficulty, Mathematics, Covid-19

Copyright (c) 2021 Siti Rahmalia Natsir, Samritin, Ekha Rosmitha Sari, Amelia Ayu Lestari, Justia, Rahmawati

$\triangle$ Corresponding author :

Email : rahmalianatsir20@gmail.com

DOI : https://doi.org/10.31004/basicedu.v5i6.1472

ISSN 2580-3735 (Media Cetak)

ISSN 2580-1147 (Media Online)

Jurnal Basicedu Vol 5 No 6 Tahun 2021 p-ISSN 2580-3735 e-ISSN 2580-1147 
5015 Analisis Kesulitan Guru Sekolah Dasar Negeri Pesisir Pantai Kota Baubau dalam Pembelajaran Matematika Pada Masa Pandemik Covid-19 - Siti Rahmalia Natsir, Samritin, Ekha Rosmitha Sari, Amelia Ayu Lestari, Justia, Rahmawati

DOI : https://doi.org/10.31004/basicedu.v5i6.1472

\section{PENDAHULUAN}

(Mata pelajaran yang sangat penting untuk dipelajari pada semua jenjang pendidikan salah satunya adalah matematika. Dengan mempelajari matematika, siswa diharapkan mampu untuk memecahkan masalah dalam kehidupan sehari-hari maupun untuk menunjang kemajuan ilmu pengetahuan dan teknologi. Matematika merupakan ilmu universal yang bermanfaat bagi kehidupan manusia dan juga mendasari perkembangan teknologi modern, serta mempunyai peran penting dalam berbagai disiplin ilmu dan memajukan daya pikir manusia. Ilmu matematika di sekolah dasar hal yang sangat penting untuk siswa, karena konsep matematika yang didapatkan pada jenjang sekolah dasar akan berpengaruh pada jenjang selanjutnya. Salah satu prinsip matematika sekolah yang dinyatakan NCTM untuk mencapai pendidikan matematika yang berkualitas tinggi yaitu belajar dan mengajar. Mengajar matematika akan efektif, memerlukan pemahaman tentang apa yang siswa ketahui dan diperlukan untuk belajar serta kemudian memberi tantangan serta dukungan agar siswa mempelajarinya dengan baik (NCTM 2000). Pada pembelajaran matematika membelajarkan tentang perhitungan, mengkaji dan menggunakan penalaran atau kemampuan individu secara logika (Kenedi, Hendri, and Ladiva 2018).

Berawal dari Cina pada tahun 2019 dunia dikagetkan dengan wabah besar yang dikenal dengan sebutan COVID-19 dan dinyatakan sebagai pandemi oleh WHO. Virus ini menyebar dari manusia ke manusia dengan sangat cepat. Penyebaran virus yang begitu cepat dan mematikan membuat sejumlah negara melakukan tindakan tegas salah satunya Indonesia. Berbagai tindakan tegas dilakukan untuk memutus mata rantai penyebaran virus COVID-19. Organisasi kesehatan dunia telah merekomendasikan standar yang harus dipatuhi untuk memutus mata rantai penyebaran virus yakni dengan mengaja jarak dan pembatasan interaksi sosial. salah satu sektor yang terkena dampak pembatasan interaksi yaitu sektor pendidikan. Menurut Organisasi Pendidikan, Ilmu Pengetahuan dan Kebudayaan Perserikatan Bangsa-Bangsa sebanyak 1.186.127.211 atau sekitar 67,7\% pelajar terganggu akan wabah ini dan negara-negara harus mengubah sistem pembelajaran meraka (Rasmitadila et al. 2020:91).

Proses pembelajaran dikelas merupakan sarana utuk membantu siswa memperoleh informasi, cara berpikir, kerampilan dan nilai yang merupakan implementasi dari kurikulum yang telah ditetapkan. Proses pembelajaran tersebut dituntut untuk diselenggaran secara interaktif, inspiratif, menyenangkan, menantang, memotovasi siswa untuk berperan aktif dalam pembelajaran, dan memberikan ruang yang cukup untuk melatih kreativitas, bakat, minat dan perkembangan fisik maupun psikologis siswa. Dengan adanya wabah saat ini, pembelajaran beralih kepembelajaran online. Baik guru dan siswa diharuskan untuk menggunakan berbagai alat dan sumber daya digital untuk mencapai tujuan pembelajaran. Menurut Soedjadi pencapaian tujuan pendidikan melalui pembelajaran matematika mengalami kesulitan, disebabkan kurang relevannya pendekatan pembelajaran yang digunakan oleh guru dengan karakteristik matematika (Siregar 2015).

Pembelajaran online pada dasarnya merupakan pembelajaran jarak jauh. Pembelajaran jarak jauh selalu menggunakan teknologi, mulai dari teknologi yang sederhana sampai teknologi yang terbaru. Yang saat ini dikenal dengan internet (Belawati 2020). Menurut Ko \& Rossen, Ogbonna dkk, Papachristos et al, Sturm \& Quaynor, dan Tarman Pembelajaran online menekankan kursus berbasis internet yang ditawarkan secara sinkron dan ansinkron. Pembelajaran secara sikron yakni bentuk pembelajaran online dengan berinteraksi langsung antar siswa dan guru sekaligus menggunakan media online seperti konferensi dan obrolan online. Sedangkan pembelajaran secara ansinkron merupakan salah satu bentuk pembelajaran secara tidak langsung atau guru dan siswa tidak langsung berkomunikasi pada waktu yang bersamaan dengan menggunakan bahan ajar dan siswa belajar secara mandiri (Rasmitadila et al. 2020:91). Sejalan dengan hal tersebut, dalam standar pelaksanaan pembelajaran (Kemendikbud 2016) menyebutkan bahwa penerapan teknologi informasi dan komunikasi secara terintegrasi, sistematis, dan efektif sesuai dengan situasi dan kondisi. 
5016 Analisis Kesulitan Guru Sekolah Dasar Negeri Pesisir Pantai Kota Baubau dalam Pembelajaran Matematika Pada Masa Pandemik Covid-19 - Siti Rahmalia Natsir, Samritin, Ekha Rosmitha Sari, Amelia Ayu Lestari, Justia, Rahmawati

DOI : https://doi.org/10.31004/basicedu.v5i6.1472

Pembelajaran yang bermakna dapat berarti proses yang digunakan untuk mengarahkan siswa pada kondisi yang membantu siswa mencapai tujuan pembelajaran, sebagaimana yang dijelaskan Nitko \& Brookhart menyatakan bahwa pembelajaran merupakan suatu proses yang guru gunakan untuk mengarahkan siswanya dengan kondisi yang membantu siswa mencapai tujuan belajar (Nitko Anthony J \& Brookhart Susan M 2019). Terdapat lima indikator pembelajaran yang efektif yakni pengelolaan pelaksanaan pembelajaran, proses komunikastif, respon peserta didik, aktifitas belajar, dan hasil belajar (Yusuf 2017). Berdasarkan indikator tersebut, dalam penelitian ini dibagi menjadi beberapa kategori yaitu kesulitan guru dalam merencanakan proses pembelajaran, kesulitan guru dalam melaksanakan proses pembelajaran dan kesulitan guru dalam berkomunikasi dengan siswa

Guru merupakan fasilitator yang harus dapat mengorganisir semua unsur-unsur pembelajaran dan mengarahkan pada semua hal yang memungkinkan siswa untuk belajar, sehingga kompetensi dan tujuan pembelajaran yang telah ditetapkan oleh guru dapat tercapai. Dengan adanya wabah COVID-19, pengetahuan guru saat ini harus diperluas dengan mempelajari dan menambah ilmu yang dibutuhkan untuk menguasai tantangan yang berkaitan dengan TIK dalam proses pembelajaran di sekolah (König, Jäger-Biela, and Glutsch 2020:611). Namun dengan keterbatasan kemampuan yang dimiliki guru sehingga menyebabkan tujuan pembelajaran tidak dapat tercapai dengan baik.

Hasil wawancara dengan guru di beberapa sekolah yang berada di pesisir pantai Kota Baubau, pembelajaran daring yang dilakukan masih kurang efektif dan terdapat banyak hambatan khususnya mata pelajaran matematika. Beberapa hambatan tersebut yakni guru kurang mampu menggunakan dan mengembangkan media pembelajaran berbasis teknologi dan informasi, hanya sebagian siswa yang memiliki fasilitas belajar online, dan kurangnya minat siswa untuk menggunakan fasilitas yang disediakan oleh sekolah jika siswa tidak memiliki fasilitas belajar online. Sejalan dengan hal tersebut, berdasarkan hasil survei cepat inovasi pembelajaran online pada tahun 2020 (Muktiono 2020) diperoleh bahwa pesan instan yang paling banyak digunakan guru adalah whatsapp dan line, pemberian dan koreksi tugas lebih sering dilakukan dibanding penyampaian materi, tugas dari buku dan tugas dari guru lebih banyak diberikan, dan koreksi skor lebih sering dibandingkan umpan balik kualitatif. Penelitian yang dilakukan oleh Wiryanto mengemukakan bahwa dampak negatif pembelajaran online yang dirasakan guru sangat besar. Dampak negatif yang dirasakan seperti tidak dapat melakukan umpan balik dengan cepat, pemahaman anak terhadap materi kurang mendalam dan tidak jelasnya penjelasan guru ketika pembelajaran online (Wiryanto 2020). Selain guru, siswa juga mengalami kesulitan dalam proses pembelajaran pada masa pandemik. Penelitian yang dilakukan Zuraida dkk menyebutkan bahwa kesulitan belajar siswa dalam pembelajaran matematika disebabkan karena siswa tidak memahami materi matematika dengan menggunakan rumus yang panjang dan membuat siswa bingung saat pembelajaran daring (Alfiyah et al. 2021). Siswa juga mengalami penurunan motivasi belajar saat pembelajaran daring. Hal ini sesuai dengan penelitian yang dilakukan An Nisa Puthree dkk yang menyebutkan bahwa faktor penyebab rendsahnya motivasi belajar siswa salah satunya yakni kejenuhan siswa dalam proses pembelajaran (Indra Kartika Sari 2021).

Berdasarkan uraian di atas, maka peneliti tertarik untuk melalukan penelitian dengan tujuan untuk mendeskripsikan jenis kesulitan yang dialami guru matematika di sekolah dasar pesisir pantai Kota Baubau dan mendeskripsikan faktor yang menyebabkan kesulitan yang dialami guru matematika di Sekolah Dasar Pesisir Pantai Kota Baubau. Manfaat dari penelitian ini yaitu menjadi masukan yang berarti bagi guru dan sekolah untuk mengevaluasi kegiatan pembelajaran matematika pada siswa. Selain itu, guru dapat memperbaiki strategi pembelajaran yang digunakan untuk membelajarkan materi matematika pada masa pandemik Covid-19. 
5017 Analisis Kesulitan Guru Sekolah Dasar Negeri Pesisir Pantai Kota Baubau dalam Pembelajaran Matematika Pada Masa Pandemik Covid-19 - Siti Rahmalia Natsir, Samritin, Ekha Rosmitha Sari, Amelia Ayu Lestari, Justia, Rahmawati

DOI : https://doi.org/10.31004/basicedu.v5i6.1472

\section{METODE PENELITIAN}

Jenis Penelitian ini adalah penelitian survei dengan pendekatan deskriptif analisis yang menggunakan data-data kemudian dianalisis dan informasi yang didapatkan dari hasil penelitian kemudian dideskripsikan untuk menghasilkan gambaran yang jelas dan terperinci mengenai kesulitan-kesulitan guru dalam pembelajaran matematika. Dalam penelitian ini, peneliti menginginkan informasi yang banyak dan beraneka ragam untuk mendeskripsikan kesulitan yang dialami oleh guru matematika Sekolah Dasar Pesisir Pantai Kota Baubau dalam melaksanakan pembelajaran pada masa Covid-19.

Penelitian ini didesain dengan tahapan sebagai berikut.

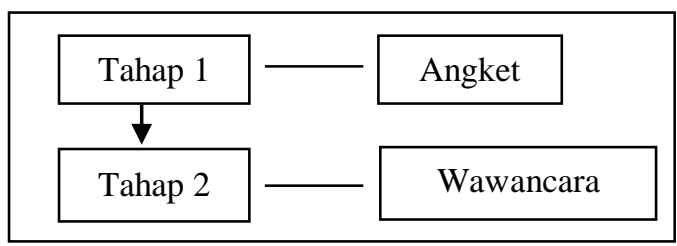

Gambar 1. Rancangan Penelitian

Keterangan:

$\longrightarrow$ : dilanjutkan ke tahap berikutnya

: bagian dari suatu tahap

Penelitian ini didesai menjadi dua tahap. Tahap pertama peneliti mengumpulkan informasi dengan memberikan angket kepada guru matematika atau guru kelas. Tahap kedua yakni pengumpulan data dengan wawancara mendalam kepada guru. Wawancara dilakukan pada saat peneliti telah mengumpulkan angket yang telah diisi oleh guru.

Populasi dalam penelitian ini adalah seluruh guru kelas sekolah dasar negeri di pesisir pantai kota Baubau. Pengambilan sampel dilakukan dengan teknik sampling purposive yaitu teknik pengambilan sampel dengan pertimbangan tertentu (Sugiyono 2015). Sampel dalam penelitian ini yaitu Sokolah Dasar Negeri di Pesisir Pantai Kota Baubau yang paling terdampak wabah Covid-19 yang terdiri dari 9 sekolah dan yang menjadi obyek penelitian ini adalah guru kelas V. Alasan peneliti mengambil guru kelas $\mathrm{V}$ yaitu karena guru kelas $\mathrm{V}$ merupakan guru yang mempersiapkan siswa masuk ke kelas ujian sehingga dianggap harus mampu melakukan proses pembelajaran dengan baik agar konsep dan pengetahuan siswa dapat tersusun dengan baik pada saat kelas ujian.

Teknik yang digunakan dalam penelitian ini adalah angket dan wawancara. Sedangkan instrumen pengumpulan datanya yaitu menggunakan lembar angket terbuka mengenai kesulitan guru dalam pembelajaran matematika dan wawancara tidak terstruktur.

Indikator dari kesulitan guru dalam penelitian ini dilihat dari segi kesulitan guru dalam perencanakan proses pembelajaran, kesulitan guru dalam melaksanakan proses pembelajaran, dan kesulitan guru dalam berkomunikasi dengan siswa. Wawancara dilakukan pada guru setelah guru mengisi angket kesulitan guru dalam pembelajaran matematika. Wawancara dalam penelitian ini dilakukan untuk memperkuat dan memperdalam data mengenai kesulitan guru dalam pembelajaran matematika.

Teknik analisis data yang digunakan dalam penelitian ini adalah teknik analisis deskrptif kualitatif dengan mengelompokan menjadi beberapa kategori antara lain kesulitan guru dalam merencanakan proses pembelajaran, kesulitan guru dalam melaksanakan proses pembelajaran dan kesulitan guru dalam berkomunikasi dengan siswa. Setelah data dikategorikan, data diolah dengan menggunakan rumus persentase sebagai berikut.

$$
P R=\frac{F R}{B R} \times 100 \%
$$


5018 Analisis Kesulitan Guru Sekolah Dasar Negeri Pesisir Pantai Kota Baubau dalam Pembelajaran Matematika Pada Masa Pandemik Covid-19 - Siti Rahmalia Natsir, Samritin, Ekha Rosmitha Sari, Amelia Ayu Lestari, Justia, Rahmawati

DOI : https://doi.org/10.31004/basicedu.v5i6.1472

Keterangan:

PJ = Persentase Jawaban Reseponden

FR = Frekuensi Jawaban Responden

$\mathrm{BR} \quad=$ Banyaknya Responden

\section{HASIL DAN PEMBAHASAN}

Berdasarkan hasil penelitian sebagian besar guru kelas yang mengajar matematika memiliki jenjang pendidikan terakhir Sarjana Pendidikan Guru Sekolah Dasar. Guru kelas V yang menjadi obyek penelitian rata-rata telah menjadi sorang PNS disekolah tersebut sehingga guru tidak lagi mengajar di sekolah lain. Pengalaman mengajar guru dalam penelitian ini yaitu rata-rata guru mengajar 10 tahun.

Kesulitan dalam merencanakan proses pembelajaran pada masa pandemic Covid-19 banyak dialami guru-guru di Pesisir Pantai Kota Baubau. Berikut kesulitan-kesulitan yang dialami guru di Pesisir Pantai Kota Baubau dalam merencanakan proses pembelajaran.

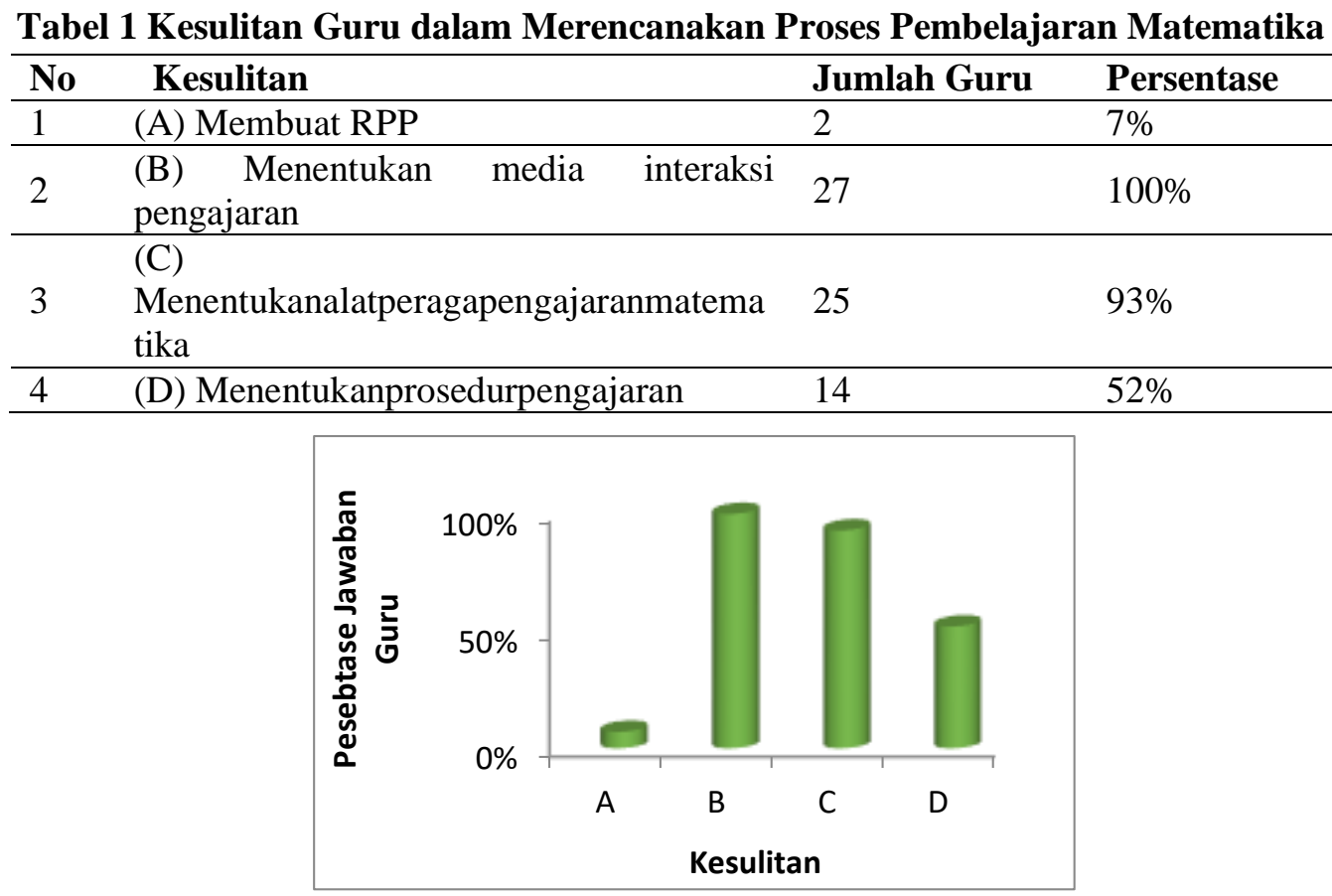

Gambar 1. Persentase Kesulitan Guru dalam Merencanakan Proses Pembelajaran

Berdasarkan tabel 1 di atas menunjukan bahwa menentukan media interaksi pengajaran matematika merupakan kesulitan yang banyak guru di pesisir pantai kota Baubau alami. Dari 27 guru Sekolah Dasar di pesisir pantai kota Baubau yang diambil datanya, semua guru mengalami kesulitan dalam menentukan media pembelajaran. Hal ini ditunjukan dengan besarnya persentase guru yakni $100 \%$. Berdasarkan hasil angket dan wawancara, hal ini terjadi karena kurangnya kemampuan guru dalam mengembangkan media interaksi pembelajaran dalam bentuk powerpoint dan video pembelajaran, sehingga guru hanya memberikan buku paket atau pun mengirimkan materi dalam bentuk file untuk dipelajari siswa pada pembelajaran jarak jauh. Selain media interaksi dalam pengajaran, banyak guru juga mengalami kesulitan dalam menentukan alat peraga dalam pembelajaran matematika. Terdapat 93\% atau 25 guru dari 27 guru sekolah dasar di Pesisir Pantai Kota Baubau yang mengalami kesulitan menentukan alat peraga. Hal ini disebabkan karena 

Matematika Pada Masa Pandemik Covid-19 - Siti Rahmalia Natsir, Samritin, Ekha Rosmitha Sari, Amelia Ayu Lestari, Justia, Rahmawati

DOI : https://doi.org/10.31004/basicedu.v5i6.1472

pembelajaran jarak jarak jauh dilakukan via Whatsapp dan classroom yang hanya dilakukan dengan mengirimkan tugas dan materi pembelajaran, sehingga untuk materi matematika yang memerlukan alat peraga untuk mempermudah memahami konsep matematika guru tidak tahu cara mempertunjukannya ke siswa.

Kesulitan berikutnya yakni menentukan prosedur pengajaran matematika. Terdapat $52 \%$ atau 14 orang guru mengalami kesulitan dalam menentukan prosedur pembelajaran matematika. Hal ini disebabkan karena banyak guru SD di Pesisir Pantai Kota Baubau melakukan pembelajaran matematika hanya menggunakan via whatsapp dengan mengirim tugas ke siswa dan $7 \%$ atau 2 orang guru mengelami kesulitan dalam membuat RPP pembelajaran jarak jauh. Hal ini disebabkan karena kurangnya pengetahuan guru dalam membuat dan mengembangkan RPP pembelajaran jarak jauh.

Data selanjutnya yang dikumpulkan dalam penelitian ini yakni kesulitan dalam melaksanakan proses pembelajaran. Berikut kesulitan-kesulitan yang dialami guru di Pesisir Pantai Kota Baubau dalam melaksanakan proses pembelajaran.

Tabel 2 Kesulitan Guru dalam Melaksanakan Proses Pembelajaran

\begin{tabular}{llll}
\hline No & Kesulitan & Jumlah Guru & Persentase \\
\hline 1 & (A) Mempraktekan metode mengajar & 8 & $30 \%$ \\
\hline 2 & (B) Menjelaskanmateri & 14 & $52 \%$ \\
\hline 3 & (C) Responsiswaterhadappembelajaran & 8 & $30 \%$ \\
\hline 4 & (D) Memotivasisiswadalambertanya & 4 & $15 \%$ \\
\hline 5 & (E) Menciptakankondisibelajar yang kondusif & 6 & $22 \%$ \\
\hline 6 & (F) Mengetahuikemampuansiswa & 12 & $44 \%$ \\
\hline 7 & (G) Alokasiwaktubelajarmengajar & 8 & $30 \%$ \\
\hline 8 & (H) Berinteraksidengansiswa & 7 & $26 \%$ \\
\hline
\end{tabular}

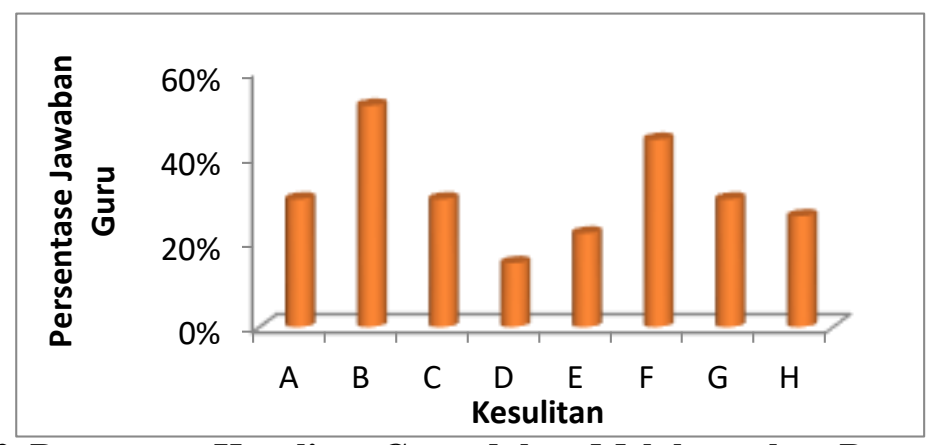

Gambar 2. Persentase Kesulitan Guru dalam Melaksanakan Proses Pembelajaran

Kesulitan yang paling banyak dialami oleh guru SD Pesisir Pantai Kota Baubau dalam proses pembelajaran yaitu menjelaskan materi kepada siswa. Terdapat $52 \%$ atau 14 orang guru yang mengalami kesulitan dalam menjelaskan materi. Hal ini disebabkan karena pembelajaran jarak jauh, guru tidak berinteraksi langsung dengan siswa. Proses pembelajaran hanya terjadi melalui whatsapp dan classroom dengan mengirim tugas dan bahan ajar ke siswa. Kesulitan selanjutnya yakni mengetahui kemampuan siswa. Berdasarkan tabel 2, terdapat $44 \%$ atau 12 orang guru mengalami kesulitan dalam mengetahu kemampuan siswa. Hal ini disebabkan karena pada proses pembelajaran jarak jauh guru tidak memiki kemampuan maupun instrumen untuk mengetahui kemampuan siswa dalam memahi materi. Sedangkan sekolah yang diberi kesempatan untuk melakukan tatap muka mengalami kesulitan pada waktu. Menurut guru waktu pembelajaran tatap muka yang diberikan tidak efektif, waktu yang diberikan hanya digunakan untuk menjelaskan materi kepada siswa yang mengalami kesulitan. 
Kesulitan selanjutnya mempraktekan metode mengajar. Hal ini disebabkan karena tidak terjadi interaksi secara langsung. Guru mengalami kesulitan dalam mencari referensi metode mengajar yang dapat digunakan dalam pembelajaran jarak jauh. Kesulitan dalam membangkitkan respon siswa terhadap pembelajaran. Hal ini disebabkan karena tidak adanya pengawasan yang baik pada saat proses pembelajaran berlangsung. Dan kesulitan dalam alokasi waktu belajar mengajar. Hal ini disebabkan karena bagi sekolah yang diperbolehkan melakukan tatap muka sesuai dengan protocol kesehatan, waktu yang diberikan sangat terbatas. Rata-rata kesulitan tersebut dialami sekitar $30 \%$ atau 8 orang guru.

Guru juga mengalami kesulitan dalam berinteraksi dengan siswa. Terdapat $26 \%$ atau 7 orang guru yang mengalami kesulitan tersebut. Hal ini disebabkan karena pembelajaran jarak jauh dimana guru tidak berinteraksi langsung dengan siswa. Keterbatasan interaksi ini disebabkan karena tidak semua siswa mempunyai fasilitas belajar online, keterbatasan paket yang dimiliki siswa, dan kendala jaringan. Kesulitan yang terakhir yakni memotivasi siswa dalam bertanya. Terdapat $15 \%$ atau 4 orang guru yang mengalami kesulitan dalam memotivasi siswa dalam bertanya pada saat proses pembelajaran. Hal ini disebabkan karena terbatasnya guru dalam berinteraksi dengan siswa karena kondisi siswa maupun guru.

Data selanjutnya yang dikumpulkan dalam penelitian ini yakni kesulitan guru SD Pesisir Pantai Kota Baubau dalam berkomunikasi dengan siswa. Berikut kesulitan-kesulitan yang dialami guru di Pesisir Pantai Kota Baubau dalam berkomunikasi dengan siswa.

Tabel 3 Kesulitan Guru dalam Berkomunikasi dengan Siswa

\begin{tabular}{lllll}
\hline No & Kesulitan & Jumlah Guru & Persentase \\
\hline 1 & (A) Membantu menumbuhkan kepercayaan diri siswa & 9 & $33 \%$ \\
\hline 2 & $\begin{array}{l}\text { (B) Menumbuhkan minat siswa dalam belajar } \\
\text { matematika }\end{array}$ & 20 & $74 \%$ \\
\hline 3 & $\begin{array}{l}\text { (C) Menumbuhkan sikap positif terhadap pelajaran } \\
\text { matematika }\end{array}$ & 9 & $33 \%$ \\
\hline
\end{tabular}

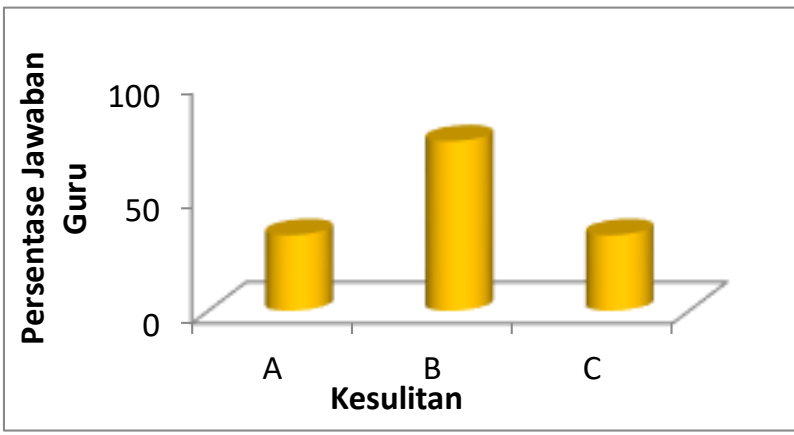

Gambar 3. Persentase Kesulitan Guru dalam Berkomunikasi dengan Siswa

Kesulitan yang paling banyak dialami oleh guru yakni menumbuhkan minat siswa dalam belajar matematika. berdasarkan table 4 terdapat $74 \%$ atau 20 orang guru mengalami kesulitan dalam menumbuhkan minat siswa dalam belajar matematika. Hal ini disebabkan karena minimnya keterlibatan guru dalam proses pembelajaran, guru menjelaskan materi dengan jarak jauh dan sering kali kondiri jaringan yang tidak memungkinkan, kebanyakan siswa pada dasarnya kesulitan dalam pelajaran matematika sehingga pembelajaran jarak jauh makin menambah kesulitan bagi siswa, kurangnya minat siswa dalam belajar matematika. Kesulitan selanjutnya yaitu membantu menumbuhkan kepercayaan diri siswa. Hal ini disebabkan karena kurangnya pengawasan dan pendampingan kepada siswa pada saat pembelajaran matematika dan kesulitan guru dalam menumbuhkan sikap positif terhadap pelajaran matematika. Hal ini disebabkan karena komunikasi yang dilakukan guru terhadap siswa kurang dikarenakan waktu yang dibatasi dalam proses 
5021 Analisis Kesulitan Guru Sekolah Dasar Negeri Pesisir Pantai Kota Baubau dalam Pembelajaran Matematika Pada Masa Pandemik Covid-19 - Siti Rahmalia Natsir, Samritin, Ekha Rosmitha Sari, Amelia Ayu Lestari, Justia, Rahmawati

DOI : https://doi.org/10.31004/basicedu.v5i6.1472

pembelajaran dan kondisi siswa yang tidak memungkinkan untuk melakukan pembelajaran jarak jauh dengan berinteraksi langsung dengan guru. Kedua kesulitan tersebut masing-masing memiliki persentase 33\% atau 9 orang guru yang mengalami kesulitan membantu menumbuhkan kepercayaan diri siswa dan menumbuhkan sikap siswa terhadap pelajaran matematika.

Hasil analisis data terdapat tiga kesulitan dalam merencenakan proses pembelajaran yang dialami guru SD Negeri Pesisir Pantai Kota Baubau yang persentasenya cukup besar yakni di atas 50\% yaitu menentukan media interaksi pengajaran matematika, menentukan alat peraga dalam pengajaran matematika dan menentukan prosedur pengajaran matematika. Terdapat berbagai faktor penghambat yang menyebabkan guru mengalami kesulitan tersebut. Penyebab kesulitan tersebut yakni kurangnya kemampuan guru dalam mengembangkan media interaksi pembelajaran dalam bentuk Power Point dan video pembelajaran, sehingga guru hanya memberikan buku paket atau pun mengirimkan materi dalam bentuk file untuk dipelajari siswa pada pembelajaran jarak jauh dan pembelajaran jarak jauh dilakukan via Whatsapp dan classroom yang hanya dilakukan dengan mengirimkan tugas dan materi pembelajaran, sehingga untuk materi matematika yang memerlukan alat peraga untuk mempermudah memahami konsep matematika guru tidak tahu cara mempertunjukannya kesiswa.

Kesulitan dalam melaksanakan proses pembelajaran juga banyak dialami oleh guru SD Negeri di Pesisir Pantai Kota Baubau. Kesulitan yang paling banyak dialami guru yaitu menjelaskan materi pelajaran matematika dan mengetahui kemampuan siswa dalam bidang matematika. Penyebab kedua kesulitan ini terjadi yaitu karena guru tidak berinteraksi langsung dengan siswa. Guru melakukan proses pembelajaran menggunakan whatsapp dan classroom dengan hanya mengirim tugas dan materi pembelajaran. Kegiatan pembelajaran tidak dilakukan dengan zoom karena terkendala pada jaringan yang kurang baik, kuota internet yang dimiliki siswa terbatas, dan sebagian siswa tidak memiliki fasilitas pembelajaran yang memadai untuk pembelajaran jarak jauh. Penelitian yang dilakukan Fadhilaturrahmi dkk juga mengungkapkan hal yang sama yakni kurang maksimalnya penyampaian materi dan sulit memahami perkembangan peserta didik (Fadhilaturrahmi, Ananda, and Yolanda 2021)

Kesulitan selanjutnya yang dianalisis dalam penelitian ini adalah kesulitan guru dalam berkomunikasi dengan siswa. Guru SD Negeri di Pesisir Patai Kota Baubau banyak mengalami kesulitan dalam menumnuhkan minat siswa dalam belajara matematika. Kesulitan ini disebabkan karena minimnya keterlibatan guru dalam proses pembelajaran, guru menjelaskan materi dengan jarak jauh dan sering kali kondisi jaringan yang tidak memungkinkan, kebanyakan siswa pada dasarnya kesulitan dalam pelajaran matematika sehingga pembelajaran jarak jauh makin menambah kesulitan bagi siswa, kurangnya minat siswa dalam belajar matematika. Sejalan dengan hal tersebut, penelitian yang dilakukan Azra dkk menyebutkan salah satu kesulitan yang dialami guru dalam pembelajaran matematika yaitu kurangnya minat belajar siswa pada pembelajaran matematika (Fauzi, Sawitri, and Syahrir 2020).

Kesulitan-kesulitan di atas dan penyebabnya sejalan dengan penelitian yang dilakukan Rasmitadila, dkk dengan judul "The Perception of Primary School Teachers of Online Learning during the COVID-19 Pandemic Period: A Case Study in Indonesia”. . Hasil penelitian tersebut yakni tantangan yang dihadapi guru dalam penelajaran online mencakup empat hal yaitu kendala teknis, pengkondisian siswa, partisipasi siswa dan pengalaman guru dalam pembelajaran online (Rasmitadila et al. 2020). Penelitian yang dilakukan Mulenga, E.M dan Marban J.M mencatat bahwa pembelajaran online berlangsung dengan baik untuk pembelajaran matematika jika dilingkungan tersebut kaya akan teknologi (Mulenga and Marbán 2020). 
5022 Analisis Kesulitan Guru Sekolah Dasar Negeri Pesisir Pantai Kota Baubau dalam Pembelajaran Matematika Pada Masa Pandemik Covid-19 - Siti Rahmalia Natsir, Samritin, Ekha Rosmitha Sari, Amelia Ayu Lestari, Justia, Rahmawati

DOI : https://doi.org/10.31004/basicedu.v5i6.1472

\section{KESIMPULAN}

Guru SD Negeri Pesisir Pantai di Kota Baubau banyak mengalami kesulitan dalam pembelajaran online selama masa pandemik COVID-19. Kesulitan yang paling banyak dialami guru dalam merencanakan proses pembelajaran yaitu menetukan media pembelajaran matematika. Hal ini disebabkan karena kurangnya kemampuan guru dalam mengembangkan media Powerpoint dalam pembelajaran dan kurangnya pengalaman guru dalam pembelajaran online. Kesulitan guru dalam melaksanakan proses pembelajaran, guru banyak mengalami kesulitan dalam menjelaskan materi matematika kesiswa dan mengetahui kemampuan siswa. Hal ini disebabkan karena guru tidak berinteraksi secara langsung dengan siswa dan terbatasnya fasilitas yang dimiliki guru maupun siswa dalam pembelajaran online. Kesulitan guru dalam berkomunikasi dengan siswa yaitu guru banyak mengalami kesulitan dalam menumbuhkan minat siswa dalam belajar matematika. Hal ini disebabkan karena guru minimnya keterlibatan guru dalam proses pembelajaran dan kurangnya pendampingan anak selama proses pembelajaran matematika. Penelitian yang dilakukan Samnufida. R, Sugiman, \& Retnawati, H mengungkapkan beberapa kesulitan guru dalam membantu perkembangan komunikasi matematis siswa, yaitu pelaksanaan proses pembelajaran, kondisi siswa dan ekonomi serta teknis pembelajaran online (Samnufida, Sugiman, and Retnawati 2021).

Peran guru dalam pembelajaran daring diantaranya yakni guru sebagai pembimbing, guru sebagai penasehat, guru sebagai pendorong kreativitas, guru sebagai actor, dan guru sebagai evaluator (Winarsieh and Rizqiyah 2020). Dengan beberapa peran tersebut, guru diharapkan mampu memaksimalkan perannya dalam proses pembelajaran. Guru juga mempunyai tanggung jawab untuk mendidik para siswa, menemukan cara yang sesuai untuk mencapai tujuan pembelajaran baik secara akademis dan social-emosional dan guru harus dapat mengelola kelas baik di kelas maupun kelas online (Setyotini 2020).

\section{UCAPAN TERIMAKASIH}

Terima kasih kepada Universitas Muhammadiyah Buton yang telah mendanai kegiatan penelitian ini, terima kasih kepada para Kepala Sekolah SD Negeri di Pesisir Pantai Kota Baubau telah memberikan izin dan kesempatan untuk melakukan penelitian dan guru-guru yang terlibat dalam penelitian ini.

\section{DAFTAR PUSTAKA}

Alfiyah, Zuraida Nisaul, Sri Hartatik, Nafilah Nafilah, And Sunanto Sunanto. 2021. "Analisis Kesulitan Belajar Matematika Secara Daring Bagi Siswa Sekolah Dasar Zuraida.” Basicedu 5(5):3158-66.

Belawati, Tian. 2020. Pembelajaran On-Line. Kedua. Banten: Universitas Terbuka.

Fadhilaturrahmi, R. Ananda, And S. Yolanda. 2021. "Persepsi Guru Sekolah Dasar Terhadap Pembelajaran Jarak Jauh Di Masa Pandemi Covid 19.” 5(3):1683-88.

Fauzi, Azra, Deni Sawitri, And Syahrir Syahrir. 2020. "Kesulitan Guru Pada Pembelajaran Matematika Di Sekolah Dasar.” Jurnal Ilmiah Mandala Education 6(1):142-48. Doi: 10.36312/Jime.V6i1.1119.

Indra Kartika Sari. 2021. "Analisis Faktor Penyebab Rendahnya Motivasi Belajar Siswa Sekolah Dasar Selama Pembelajaran Daring.” Jurnal Basicedu 5(4):2156-63.

Kemendikbud. 2016. "Peraturan Menteri Pendidikan Dan Kebudayaan Nomor 22 Tahun 2016 Tentang Standar Proses Pendidikan Dasar Dan Menengah."

Kenedi, A. K., S. Hendri, And H. B. Ladiva. 2018. "Kemampuan Koneksi Matematis Siswa Sekolah Dasar Dalam Memecahkan Masalah Matematika." Numeracy Journal 5(2):226-35.

König, Johannes, Daniela J. Jäger-Biela, And Nina Glutsch. 2020. “Adapting To Online Teaching During 
5023 Analisis Kesulitan Guru Sekolah Dasar Negeri Pesisir Pantai Kota Baubau dalam Pembelajaran Matematika Pada Masa Pandemik Covid-19 - Siti Rahmalia Natsir, Samritin, Ekha Rosmitha Sari, Amelia Ayu Lestari, Justia, Rahmawati

DOI : https://doi.org/10.31004/basicedu.v5i6.1472

Covid-19 School Closure: Teacher Education And Teacher Competence Effects Among Early Career Teachers In Germany." European Journal Of Teacher Education 43(4):608-22. Doi: 10.1080/02619768.2020.1809650.

Muktiono, Waspodo. 2020. "Pembelajaran Daring Di Mada Pandemi Covid 19.” Pusliyjak, Balitbang Dan Perbukuan, Kemendikbud. Retrieved (Https://Puslitjakdikbud.Kemdikbud.Go.Id/).

Mulenga, Eddie M., And José M. Marbán. 2020. "Prospective Teachers' Online Learning Mathematics Activities In The Age Of Covid-19: A Cluster Analysis Approach.” Eurasia Journal Of Mathematics, Science And Technology Education 16(9). Doi: 10.29333/Ejmste/8345.

Nctm. 2000. Prinsiple And Standars For School Mathematics. Reston, Va.

Nitko Anthony J \& Brookhart Susan M. 2019. Educational Assesment Of Students. 8 Th. Bonton, Ma: Pearson Educational.

Rasmitadila, Rusi Rusmiati Aliyyah, Reza Rachmadtullah, Achmad Samsudin, Ernawulan Syaodih, Muhammad Nurtanto, And Anna Riana Suryanti Tambunan. 2020. "The Perceptions Of Primary School Teachers Of Online Learning During The Covid-19 Pandemic Period: A Case Study In Indonesia." Journal Of Ethnic And Cultural Studies 7(2):90-109. Doi: 10.29333/Ejecs/388.

Samnufida, R., Sugiman, And H. Retnawati. 2021. "Teacher's Difficulties Junior High School Communication Mathematics During Online Learning." Aksioma 10(2):774-85. Doi: Https://Doi.Org/10.24127/Ajpm.V10i2.3467.

Setyotini, I. 2020. "Terhadap Proses Pembelajaran Pada Kurukulum 13 ? Journal Of Industrial Engineering \& Management Research ( Jiemar ).” 01(Juni):95-102. Doi: Https://Doi.Org/10.7777/Jiemar.V1i1.

Siregar, Yulinda. 2015. "Kompetensi Guru Dalam Bidang Strategi Perencanaan Dan Pembelajaran Matematika." Formatif: Jurnal Ilmiah Pendidikan Mipa 3(1):39-48. Doi: 10.30998/Formatif.V3i1.114.

Sugiyono. 2015. Metode Penelitian Pendidikan (Pendekatan Kuantitatif, Kualitatif Dan R\&D). Bandung: Alfabeta.

Winarsieh, I., And I. P. Rizqiyah. 2020. "Peran Guru Dalam Pembelajaran Daring Pada Masa Pandemi Covid19.” Indonesia Journal Of Teacher Education 1(4):159-64.

Wiryanto. 2020. "Proses Pembelajaran Matematika Di Sekolah Dasar Di Tengah Pandemi Covid-19." Jurnal Review Pendidikan Dasar: Jurnal Kajian Pendidikan Dan Hasil Penelitian 6(2):125-32.

Yusuf, Bistari Basuni. 2017. "Konsep Dan Indikator Pembelajaran Efektif." Jurnal Kajian Pembelajaran Dan Keilmuan 1(2):13-20. 